\title{
Depression, Occupational Anxiety, and Related Factors in Medical Students
}

\author{
Meltem Gürüi1D, Gül Ferda Cengiz ${ }^{2} \mathbb{D}$ \\ 1 Gazi University, Directorate of Health, Culture and Sport, Division of Psychiatry, Ankara, Turkey \\ 2 Bozok University Faculty of Medicine, Department of Psychiatry, Yozgat, Turkey
}

\begin{abstract}
Background: Depression occupies an important place in medical students' psychiatric disorders, with a prevalence of approximately 20-40\%. We aim to examine factors that might affect depression in medical students and investigate the relationship between occupational anxiety and depression severity.

Methods: Eighty-eight medical students who were diagnosed with major depressive disorder were included in the study. A Sociodemographic Data Form, the Occupational Anxiety Questionnaire for Medical Students, Beck Depression Inventory, and Beck Anxiety Inventory were used.

Results: A statistically significant relationship was found between academic success, living with family, Occupational Anxiety Questionnaire for Medical Students, and Beck Depression Inventory scores. The mean value of the occupational anxiety of the students was 35.87 \pm 9.82 . The most anxious options for students in the Occupational Anxiety Questionnaire for Medical Students were the inability to prepare for and pass the Central Medical Specialty Exam.

Conclusions: It is necessary to focus on factors that may affect the severity of depression, which affect both the social and professional lives of medical students who are physician candidates. The issues about occupational anxiety should be considered when planning medical school education and postgraduate working conditions.
\end{abstract}

Keywords: Depression, Anxiety, Medical Students.

\section{INTRODUCTION}

University life is a period in which students receive education related to their profession, prepare for adulthood and working life (1). It is known that medical education, which is one of the fields of education at university, is a challenging and lengthy process. Unfortunately, many studies show that medical students have higher rates of depression than students of other faculties and the general population (2).
The lifetime prevalence of the major depressive disorder is between $17 \%$ and $21 \%$, and according to the World Health Organization (WHO) data, it is the mental illness that ranks first among the causes of disability(3). Studies conducted with university students stated that depression is the most important mental disorder seen in university students(4).

Medical schools have long been considered stressful environments for students entering tertiary education. 
Among the factors that negatively affect the mental state of medical students, many factors such as academic pressure created by the high expectations of society and families, the difficulty of medical education, frequency of examinations, the intense workload that occurs with the transition to clinical classes, sleep deprivation, little time for hobbies, social isolation are reported $(5,6)$. These factors negatively affect students' academic performance, physical health, and psychological status, making them more susceptible to depression.

Depression is a problem that should be addressed for medical students because of the prevalence of suicidal ideas in medical students, causing alcohol or substance abuse, depressive symptoms tend to become chronic, its treatment is complex, and it can affect their future professional life $(7,8)$. In this context, we aimed to examine factors that might affect depression in medical students and investigate the relationship between occupational anxiety and depression severity.

\section{MATERIALS AND METHODS}

One hundred twenty-two medical students who were admitted to University Health Care Center Psychiatry outpatient clinic between October 2018 and February 2020 were evaluated. Among these, patients with depressive symptoms such as sadness, tearfulness, emptiness, loss of interest or pleasure in most activities, sleep and appetite problems, concentrating problems were included in the study. The study population consisted of eighty-eight patients diagnosed as major depressive disorder. The participants were informed about the study, and their informed consent was obtained. Permission was obtained from the Gazi University Ethics Committee for the research (Decision No.: 91610558-604.01.02, Decision Date: 04.02.2020).

In this study, a Sociodemographic Data Form, the Occupational Anxiety Questionnaire for Medical Students (OAQ), Beck Depression Inventory (BDI), and Beck Anxiety Inventory (BAI) were used.

\section{Sociodemographic Data Form}

A Sociodemographic Data Form was prepared by the researchers in line with the literature. It consisted of questions including age; sex; marital status; whether they were a foreign national; academic year; history of having to repeat academic years and how many years if any; whether they studied medicine in English or Turkish; whether they lived with their family; whether they had a history of alcohol or substance use, depression attack, and a family history of depression.

\section{Occupational Anxiety Questionnaire for Medical Students (OAQ)}

In the study conducted by Ergin et al., the OAQ was used to evaluate occupational anxiety levels of medical students (9). The OAQ, which consists of 17 parameters, includes factors that can cause anxiety about work environment and conditions, occupational competence, and occupational satisfaction. The minimum available score is 17 , and the maximum is 68 points from the questionnaire, and as the score increases, the students' occupational anxiety also increases; $17-33$ points are considered as low, 34-50 points as a medium, and 51-68 points as high occupational anxiety.

\section{Beck Depression Inventory (BDI)}

The BDI was developed by Beck (10) and adapted to Turkish (11). It is a self-report scale with 21 items measuring emotional, cognitive, somatic, and motivational symptoms. The items of the scale are scored between 0 and 3 points. Total scores of $0-12$ indicated minimal, 13-18 mild, 19-28 moderate, and 29-63 severe depression.

\section{Beck Anxiety Inventory (BAI)}

The BAI is an inventory designed to assess physical, emotional, and cognitive aspects of anxiety and fear of losing control. It was developed by Beck et al. (12) and adapted to Turkish by Ulusoy et al. (13). The scale, consisting of 21 questions, is scored between $0-3$, and the severity of anxiety symptoms is determined based on the total score. The total score ranges from $0-63$ points.

\section{Statistical Analysis}

All data were analyzed using the Statistical Package for the Social Sciences (SPSS) Ver. 15 software package. Categorical data are presented as percentages and numbers, and as mean and standard deviation values for continuous data. Whether the variables showed normal distribution was evaluated using the Kolmogorov-Smirnov test. Pearson/ Spearman correlation analyses were used to determine the relationship between variables. $\mathrm{P}<0.05$ was accepted for the significance level. 


\section{RESULTS}

Eighty-eight medical students were diagnosed as having major depressive disorder according to the Diagnostic and Statistical Manual of Mental Disorders, Fifth Edition (DSM-5) diagnostic criteria were evaluated.
The sociodemographic information and clinical characteristics of the students were presented in Table 1.

Table 1. Sociodemographic information and clinical characteristics of the students

\begin{tabular}{|c|c|c|c|}
\hline & & $\mathrm{n}$ & $(\%)$ \\
\hline Age & $\begin{array}{l}\text { mean } \\
\text { min } \\
\max \end{array}$ & $\begin{array}{l}21.75 \\
18 \\
31\end{array}$ & \\
\hline Gender & $\begin{array}{l}\text { female } \\
\text { male }\end{array}$ & $\begin{array}{l}42 \\
46\end{array}$ & $\begin{array}{l}47.7 \\
52.3\end{array}$ \\
\hline Marital status & $\begin{array}{l}\text { single } \\
\text { married }\end{array}$ & $\begin{array}{l}86 \\
2\end{array}$ & $\begin{array}{l}97.7 \\
2.3\end{array}$ \\
\hline International students & & 5 & 5.7 \\
\hline Grade & $\begin{array}{l}\text { grade 1 } \\
\text { grade 2 } \\
\text { grade 3 } \\
\text { grade 4 } \\
\text { grade 5 } \\
\text { grade 6 }\end{array}$ & $\begin{array}{l}17 \\
15 \\
12 \\
18 \\
15 \\
11\end{array}$ & $\begin{array}{l}19.3 \\
17.0 \\
13.6 \\
20.5 \\
17.0 \\
12.5\end{array}$ \\
\hline Existance of grade repetition & $\begin{array}{l}\text { yes } \\
\text { no }\end{array}$ & $\begin{array}{l}22 \\
66\end{array}$ & $\begin{array}{l}25 \\
75\end{array}$ \\
\hline The number of grade repetitions & $\begin{array}{l}1 \text { year } \\
2 \text { years } \\
3 \text { years }\end{array}$ & $\begin{array}{l}14 \\
4 \\
4\end{array}$ & $\begin{array}{l}15.9 \\
4.5 \\
4.5\end{array}$ \\
\hline Received medical education in English & & 4 & 4.5 \\
\hline Students living with their families & & 33 & 37.5 \\
\hline Family history of psychiatric treatment & $\begin{array}{l}\text { yes } \\
\text { no }\end{array}$ & $\begin{array}{l}18 \\
70\end{array}$ & $\begin{array}{l}20.5 \\
79.5\end{array}$ \\
\hline History of depression attack & $\begin{array}{l}\text { yes } \\
\text { no }\end{array}$ & $\begin{array}{l}45 \\
43\end{array}$ & $\begin{array}{l}51.1 \\
48.9\end{array}$ \\
\hline Alcohol abuse & $\begin{array}{l}\text { yes } \\
\text { no }\end{array}$ & $\begin{array}{l}2 \\
86\end{array}$ & $\begin{array}{l}2.3 \\
97.7\end{array}$ \\
\hline Substance abuse & $\begin{array}{l}\text { yes } \\
\text { no }\end{array}$ & $\begin{array}{l}1 \\
87\end{array}$ & $\begin{array}{l}1.1 \\
98.9\end{array}$ \\
\hline
\end{tabular}

min: minimal, max: maximal, $\mathrm{n}$ : number of patients 
Students' BDI, BAI, OAQ score averages, and OAQ levels were shown in Table 2. The mean value of the professional anxiety level of the students was $35.87 \pm 9.82$.

Table 2. Students' BDI, BAI, OAQ score averages, and OAQ levels

\begin{tabular}{|l|l|}
\hline & mean \pm SD \\
\hline BDI & $22.84 \pm 9.24$ \\
\hline BAI & $19.78 \pm 10.93$ \\
\hline OAQ & $35.87 \pm 9.8$ \\
\hline OAQ levels & $\mathbf{n}(\%)$ \\
\hline Mild & $36(40.9 \%)$ \\
Moderate & $44(50.0 \%)$ \\
Severe & $8(9.1 \%)$ \\
\hline
\end{tabular}

BDI: Beck Depression Inventory

BAI: Beck Anxiety Inventory

OAQ: Occupational Anxiety Questionnaire for Medical Students

SD: standart deviation

n: number of patients

The distribution of the reasons for the occupational anxiety of the students was presented in Table 3. The most anxious options for students in the OAQ were the inability to prepare for and pass the TUS (Central Medical Specialty Exam).

Table 3. The reasons for the occupational anxiety of the students

\begin{tabular}{|l|l|}
\hline & $\mathrm{n}(\%)$ \\
\hline Not being able to prepare for TUS & $45(51.1)$ \\
\hline Not being able to pass TUS & $45(51.1)$ \\
\hline $\begin{array}{l}\text { Dealing with the emergency patient in } \\
\text { professional life }\end{array}$ & $42(47.7)$ \\
\hline Not being a specialist doctor & $35(39.8)$ \\
\hline Be assigned to undesirable place & $28(31.9)$ \\
\hline Working in primary care health services & $28(31.8)$ \\
\hline Lower income in professional life & $28(31.8)$ \\
\hline $\begin{array}{l}\text { Harm someone inadvertently during } \\
\text { professional life }\end{array}$ & $24(27.3)$ \\
\hline Lack of clinical skills during professinal life & $19(21.6)$ \\
\hline $\begin{array}{l}\text { Being insufficient in prescribing during } \\
\text { professional life }\end{array}$ & $22(25)$ \\
\hline Being uncertain about the place of work & $21(23.8)$ \\
\hline Misdiagnosing patients in professional life & $23(26.2)$ \\
\hline $\begin{array}{l}\text { Communicating with the personnel of the } \\
\text { health care facility }\end{array}$ & $20(22.7)$ \\
\hline Working as an assistant doctor & $19(21.6)$ \\
\hline Become unemployed & $19(21.6)$ \\
\hline Working away from university & $16(18.2)$ \\
\hline Coping with the patient alone in professional life & $14(15.9)$ \\
\hline
\end{tabular}

TUS: Central Medical Specialty Exam, n: number of patients
Table 4 shows the relationship of some sociodemographic variables with the BDI scores. A statistically significant relationship was found between the existence of year repetition, the number of year repetitions, the status of living with their family, and total BDI scores (p: 0.003, p: $0.002, \mathrm{p}<0.001)$.

Table 4. The relationship of some sociodemographic variables with the BDI score

\begin{tabular}{|l|l|l|}
\hline BDI & r/rho & $\mathrm{p}$ \\
\hline Age & 0.073 & 0.572 \\
\hline Grade & -0.139 & 0.098 \\
\hline Existance of grade repetition & $0.316^{* *}$ & 0.003 \\
\hline The number of grade repetitions & $0.328^{* *}$ & 0.002 \\
\hline Students living with their families & $-0.372^{* *}$ & 0.000 \\
\hline
\end{tabular}

BDI: Beck Depression Inventory

r: Pearson's correlation coefficient

rho: Spearman's correlation coefficient

${ }^{* *}: \mathrm{p}<0.01$

*: $p<0.05$

A statistically significant correlation was found between total OAQ scores and BDI and BAI total scores $(\mathrm{p}<0.001$, $\mathrm{p}<0.001)$.

\section{DISCUSSION}

In many parts of the world, medical students are at risk for psychiatric diseases, especially depression (6). In this study, we aimed to examine the factors that may affect the depression in medical students and investigate the relationship between occupational anxiety and depression severity.

Our study observed that gender, one of the sociodemographic factors, did not affect the total BDI scores. When studies investigating depression in medical students were examined, some reported that depression was more frequent and severe in women, whereas others declared that gender did not affect depression $(14,15)$. The total BDI scores of two students who were married were higher than those who were single. However, this was not statistically significant because very few students were married among the sample. The total BDI scores of five international students were higher than those of Turkish students. Although these data were not statistically significant given the small number of international students, it is known that international students have 
difficulties in many issues such as decreased academic success due to issues such as language problems, accommodation problems, and economic problems. Two students whose marital status was married were among the international students.

Although there was no statistically significant relationship between the years and the BDI total scores, it is seen in Table 1 that most applicants were from the fourth and first-year students, respectively. This condition may be due to the intense workload that occurs with the transition to clinical classes in the fourth year and the adaptation to the new school and accommodation environment in the first year. There are studies in the literature showing that depression increases with advancing school years $(16,17)$. In the study of Eyüboğlu et al., in which first and sixthyear medical students were compared, they stated that the severity and frequency of depression were higher in sixthyear students (15). The total BDI scores of students with a history of repeating academic years were higher than students without a history of year repetition. Also, total BDI scores were higher in students who had a history of repeating academic years of more than one year compared with students with one year of year repetition. Similar results were found in studies evaluating depression in medical students. It was shown that students who stated that their course success was poor had more depression $(14,18)$. As reported by Tunç and Yapıcı in their studies evaluating 631 medical students, it can be planned to monitor the academic success of medical students during the education process, to evaluate the mental status of students who are considered to be in need, and to support those who have problems (14).

Four of the 88 students included in the study studied medicine in English. Although not statistically significant, the total BDI scores of the students who received medical education in English were higher than those who received medical education in Turkish. Students who received medical education in English verbally stated that they had more academic difficulties than students who received medical education in Turkish, especially in the first years of their theoretical education.

In our study, the total BDI scores of students living with their families were lower than those of students who did not live with their families. This result may be due to having to deal with housework after the intensity of education in the school/hospital during the day, problems with adaptation to the environment if staying in the dormitory, and not getting enough social support due to being away from home. In the study conducted by Roh et al., it was determined that the prevalence of depression in medical students living alone was higher than those living with their family or relatives (18).

Family depression history and previous depression history are important factors affecting the frequency and severity of depression $(19,20)$. In our study, no statistically significant difference was found between the total BDI scores of students with a family history of psychiatric treatment and the total BDI scores of students who did not have a family history of psychiatric treatment. Although the total BDI scores of the students with a history of depression attack were higher, no statistically significant difference was found with the BDI total scores of the students who had no history of psychiatric admission. It can be thought that these results may be related to the small sample size. This item was not evaluated due to the small number of students with an alcohol/substance abuse history.

In our study, it was found that the occupational anxiety levels of the students were at a medium level, and the areas they were most anxious about were not being able to prepare for the TUS exam and not being able to pass TUS. A significant number of physicians who have completed primary medical education in our country choose to continue their medical education after graduation and specialize in a particular field by taking the TUS (18). Although fresh graduates prepare for the TUS due to reasons such as professional ideals, career plans, economic concerns, difficulties of working as a general practitioner, concerns about malpractice, and the effects of workload on private life (21), especially with the effect of increasing medical faculty quotas, it is getting harder and harder to pass the TUS (22).

One of the most anxious items in the OAQ was dealing with emergency patients in professional life. Students preparing for the TUS with the mindset of becoming specialists from the early years of medical faculty spend most of their time in training centers for the TUS, starting from the fourth year (23). Fresh graduate physicians are educated with the knowledge of rare diseases in society in detail and equipped with knowledge that requires an advanced level of expertise $(24,25)$. It is thought that this may cause students to avoid being alone with patients 
and coping with emergency patients owing to not being able to master the basic health problems of society and not knowing treatment methods very well (6). Another reason students worry about dealing with emergency patients in their professional lives is the lack of practical training before graduation. In the study conducted by Yalçınoğlu et al. with 346 students, the rate of students who considered themselves sufficient to become a physician after the theoretical and practical training they received was $14.8 \%$. In the same study, it was found that $70.5 \%$ of students were anxious about approaching emergency patients due to deficiencies in practical education (26).

A statistically significant correlation was found between total OAQ scores and BDI and BAI total scores in our study. In other words, as the professional anxiety levels of students increase, the symptoms of depression and anxiety increase. Considering that depression and anxiety are common and intertwined clinical diagnoses, it can be thought that students with high professional anxiety are at risk for depression and anxiety disorders.

Although studies have investigated depression in medical students, few have investigated its relationship with occupational anxiety. Another important aspect of our study is that the students were evaluated through face-toface interviews by a psychiatrist under the conditions of an examination room. Our study's limitations are the small sample size, the fact that it was performed only in one medical faculty, and also collecting data by self-reported tests. Also, the OAQ, BDI, and BAI scores of the students who were obtained during an examination period, which may have affected the situation.

Studies have shown that medical students do not get enough psychiatric support compared with the general population, even though they are close to the hospital, and that students do not prefer psychiatric help because of stigmatization $(27,28)$. To prevent this situation, since October 2018, all medical students who want to receive psychiatric help in our university are examined in the psychiatry department of the Health Care Center located in the central campus instead of University Medical Faculty Hospital. Also, regular meetings with the psychologists of the University Health Care Center are planned for students in need. In this way, students can reach psychiatric support more easily without worrying about being stigmatized, and students with depressive symptoms have interventions earlier.
In conclusion academic failure, living far away from family and professional anxiety scores were associated with high BDI scores in medical students. The most anxious issues in OAQ were related to the TUS and dealing with emergency patients. It is necessary to focus on these factors that may affect the severity of depression in affecting both the social and professional lives of medical students. These issues should be taken into consideration when planning medical faculty education and postgraduate working conditions.

\section{Declarations}

The authors received no financial support for the research and/or authorship of this article. There is no conflict of interest.

Permission was obtained from the Gazi University Ethics Committee for the research (Decision No.: 91610558-604.01.02, Decision Date: 04.02.2020).

\section{REFERENCES}

1. Çivitçi A. Üniversite öğrencilerinde genel yaşam doyumu ve psikolojik ihtiyaçlar arasındaki ilişkiler. Üniversite öğrencilerinde genel yaşam doyumu ve psikolojik ihtiyaçlar arasındaki ilişkiler, Ç.Ü. Sosyal Bilimler Enstitüsü Dergisi. 2012;21(2):321-336

2. Puthran R, Zhang MW, Tam WW, Ho RC. Prevalence of depression amongst medical students: a meta-analysis. Med Educ. 2016;50(4):45668

3. World Health Organization. Depression. 2008. Avaliable at: www. who.int/ mental_health/management /depression/definition/en/. Accessed October 23, 2008.

4. Deveci SE, Ulutaşdemir N, Açı Y. Bir sağlık yüksekokulu ögrrencilerinde depresyon belirtilerinin görülme sıklı̆̆ı ve etkileyen faktörler. Fırat Tıp Dergisi. 2013; 18(2): 98-102

5. Imran N, Tariq KF, Pervez MI, Jawaid M, Haider II. Medical students' stress, psychological morbidity, and coping strategies: a cross-sectional study from Pakistan. Acad Psychiatry. 2016;40(1):92-6.

6. Hofbauer VS, Holzinger A. How to cope with the challenges of medical education? Stress, depression, and coping in undergraduate medical students. Acad Psychiatry. 2020; 44:380-387.

7. Dyrbye LN, Thomas MR, Massie FS, Power DV, Eacker A, Harper W, et al. Burnout and suicidal ideation among US medical students. Ann Intern Med. 2008;149 (5):334-41.

8. Öncü B, Şahin T, Özdemir S, Şahin C, Çakır K, Öcal E. Tıp fakültesi öğrencilerinde depresyon, anksiyete ve stres düzeyleri ve ilişkili etmenler. Kriz Dergisi. 2013;21 (1):1-10.

9. Ergin A, Uzun SU, Topaloğlu S. Pamukkale Üniversitesi Tıp Fakültesi 5. ve 6. Sınıf Öğrencilerinin Sürekli Kaygı ve Mesleki Kaygı Düzeyleri ve Bunları Etkileyen Etkenler. Muğla Sıtkı Koçman Üniversitesi Tıp Dergisi. 2016;3(3):16-21.

10. Beck AT. An inventory for measuring depression. Arch Gen Psychiatry. 1961; 4:561-571.

11. Hisli N. Beck Depresyon Envanterinin geçerliliği üzerine bir çalışma. Psikoloji Dergisi. 1988; 6: 118-121. 
12. Beck AT, Epstein N, Brown G, Steer RA. An inventory for measuring clinical anxiety: psychometric properties. J Consult Clin Psychol. 1988;56(6):893-7.

13. Ulusoy M, Sahin NH, Erkmen H. Turkish version of the Beck anxiety inventory. J Cogn Psychother. 1988;12(2):163-172.

14. Tunç AY, Yapıcı G. Bir tıp fakültesindeki öğrencilerin depresyon, anksiyete ve stres düzeylerinin değerlendirilmesi. Turk J Public Health. 2019;17(2):153-168.

15. Eyüboğlu M, Eyüboğlu D, Duran O, Karademir SB, Karaaslan F, Alyu FM. Depression, anxiety, sleep problems and suicidal behavior among medical students: A cross-sectional comparison study between first and sixth year students. J Clin Psy. 2021; 24(1): 61-68.

16. Roberts LW, Warner TD, Trumpower D. Medical students' evolving perspectives on their personal health care: clinical and educational implications of a longitudinal study. Compr Psychiatry. 2000;41:303314.

17. Dahlin M, Joneborg N, Runeson B. Stress and depression among medical students: a cross-sectional study. Med Educ. 2005;39(6):594604.

18. Roh MS, Jeon HJ, Kim H, Han SK, Hahm BJ. The prevalence and impact of depression among medical students: a nationwide crosssectional study in South Korea. Acad Med. 2010;85(8):1384-90.

19. Klein DN, Glenn CR, Kosty DB, Seeley JR, Rohde P, Lewinsohn PM. Predictors of first lifetime onset of major depressive disorder in young adulthood. J Abnorm Psychol. 2013;122(1):1-6.

20. Solomon DA, Keller MB, Leon AC, Mueller TI, Lavori PW, Shea MT, et al. Multiple recurrences of major depressive disorder. Am J Psychiatry 2000; 157:229-233.

21. Akinci E. The associations of temperament, character, anxiety, and specialty choice among sixth-year medical students: a cross-sectional study. Dusunen Adam. 2020;33:170-179.

22. A Mayda, M Yılmaz, B Filiz, Deler MH, Demir H, Doğru M, et al. Bir tıp fakültesi 4, 5 ve 6. sınıf öğrencilerinde gelecek ile ilgili kaygı durumunun değerlendirilmesi DÜ Sağlık Bil Enst Derg. 2014;4(3): 7-13.

23. Yıldırım Dİ, Marakoğlu K. Tıp fakültesi internlerinin tıp eğitimi ile tıpta uzmanlık sınavı hakkındaki düşünceleri ve branş tercihlerinin belirlenmesi. Genel Tip Derg. 2019;29(4):183-189.

24. Kılıç B, Sayek İ. Türk tabipleri birliği mezuniyet öncesi tıp eğitimi raporu-2000 (TTB-MÖTER). Toplum ve Hekim. 2001;16:230-40.

25. Terzi C, Saçaklığlu F, Sayek İ. 2020 yılında Türkiye'de tıp eğitimi. 2000-2020 sürecinde nasıl bir dünya, Türkiye, sağlık, tıp ortamı öngörülebilir, oluşturulabilir? Ankara: TTB Yayını. 2002;157-94.

26. Yalçınoğlu N, Kayı İ, Işık Ş, Aydın T, Zengin Ş, Karabey S. İstanbul Üniversitesi İstanbul Tıp Fakültesi Son Sınıf Öğrencilerinin Tıp Eğitimi İle İlgili Görüşleri. İst Tıp Fak Derg 2012; 75: 41-5.

27. Rosenthal JM, Okie S. White coat, mood indigo depression in medical school. N Engl J Med. 2005;353:1085-1088.

28. Schwenk TL, Davis L, Wimsatt LA. Depression, stigma, and suicidal ideation in medical students. JAMA. 2010;304:1181- 1190. 